\title{
Pendidikan Inklusif Perspektif QS. Al-Hujurat Ayat 10-13 Sebagai Solusi Eksklusifisme Ajaran di Sekolah
}

\author{
DAIMAH \\ Universitas Islam Negeri Sunan Kalijaga Yogyakarta \\ Jl. Marsada Adisucipto Yogyakarta Kode Pos 55281 \\ Email: sholihahdaimah@gmail.com
}

\begin{abstract}
The rise of acts of anarchism and terrorism has become the central problem in the life of the nation in Indonesia. This is due to the increasingly blurred public awareness of multi-ethnic and multi-religious plurality that grows in diverse societies. One solution is to introduce inclusive education starting in school. The concept of inclusive education in the teachings of Islam is embodied in the holy book of the Qur'an. In it, it is explained that people in this world are created with multi-ethnicity to know each other and mutual respect. With the method of library research the authors do an analysis of the concept of inclusive education in Qs Al-Hujurat verses $10-13$ which in this case will the author make the foundation as a solution indoctrination of Islamic education in the School. Inclusive education is a conscious effort to mature man through a structured and continuous effort with an open, dynamic and rational learning system. To achieve a peace and prosperity in the community needs to be mutually open attitude begins with the willingness to know each other and appreciate the difference by not discriminating against certain groups. This will be accomplished by introducing, inclusive education starting from school.
\end{abstract}

\section{Keywords: Inclusive Education, Exclusive Doctrine, Islamic Education}

Abstrak: Maraknya aksi anarkis dan terorisme belakangan menjadi problematika sentral dalam kehidupan berbangsa di Indonesia. Hal ini terjadi karena semakin kaburnya kesadaran masyarakat tentang pluralitas multi-etnik dan multi-agama yang tumbuh dalam masyarakat yang berbhineka. Salah satu solusinya adalah dengan mengenalkan pendidikan inklusif (terbuka) dimulai sejak dibangku sekolah.Konsep pendidikan inklusif dalam ajaran agama Islam termaktub dalam kitab suci Al-Qur'an. Didalamnya, dijelaskan bahwa manusia didunia ini diciptakan dengan multi-etnis untuk saling mengenal dan saling menghormati.Dengan metode library research penulis melakukan analisis terhadap konsep pendidikan inklusif dalam QS. Al-Hujurat ayat 10 13 yang dalam hal ini akan penulis jadikan landasan sebagai solusi indoktrinasi pendidikan Islam di Sekolah. Pendidikan inklusif merupakan usaha sadar mendewasakan manusia melalui upaya yang terstruktur dan berkesinambungan dengan sistem pembelajaran yang terbuka, dinamis dan rasional. Untuk mencapai suatu kedamaian dan kesejahteraan dalam bermasyarakat perlu adanya sikap saling terbuka dimulai dengan adanya kesediaan untuk saling mengenal antara satu sama lain dan menghargai perbedaan dengan tidak melakukan diskriminasi terhadap golongan tertentu. Hal tersebut akan terlaksana dengan mengenalkan pendidikan Inklusif yang terbuka dimulai dari bangku sekolah.

Kata Kunci: Pendidikan Inklusif, Eksklusif Ajaran, Pendidikan Islam 


\section{PENDAHULUAN}

Inklusifitas agama belakangan ini menjadi isu sentral dalam mengembangkan teologi. Munculnya isu ini disebabkan karena semakin kaburnya kesadaran masyarakat tentang pluralitas yang meniscayakan multi-etnik dan multiagama yang tumbuh dalam masyarakat yang berbineka. Pada saat ini khususnya di Indonesia, toleransi etnik dan agama di Indonesia menjadi agenda penting sejak maraknya kekerasan etnik agama serta gencarnya kasus-kasus teror yang ditebar atas nama agama (Hujair, 2017: 3).

Sudah ada beberapa penelitian yang meneliti sikap dan pengetahuan di sekolah negeri khususnya berkaitan dengan pandangan dan sikap keagamaan. Penelitian ini diantaranya dilakukan oleh Wahid fondation dengan laporannya yang berjudul "Laporan Riset dan Potensi Radikalisme dikalangan Aktivis Rohani Islam di Sekolah Negeri" pada tanggal 3 mei 2016. Hasil riset diantaranya menunjukkan bahwa materi pengajian rohis rata-rata $20 \%$ adalah konten pengajian rohis yang memuat : kebencian terhadap agama lain, perlawanan bahkan perang, terhadap umat lain atau pemerintah yang memusuhi atau mengancam umat Islam; perang pemikiran (Gazbul Fikri) untuk meracuni dengan berbagai pemikiran menyimpang, agama atau keyakinan menjadi faktor utama untuk memilih teman.

Selain itu diantara anggota rohis itu, ditemukan $82 \%$ adalah orang yang aktif mengikuti pengajian rohis dan yang berperan menmicu kecenderungan yang mempengaruhi di rohis itu adalah pembimbing, pemateri dan ustad dalam pengajian rohis yang tercatat $50 \%$ guru agama, dan selain itu adalah alumni, kakak kelas, pihak lain, dan mahasiswa non alumni. Hasil menggambarkan suatu kegelisahan yang perlu menjadi renungan bersama untuk mempertimbangkan dan melakukan perubahan karakter dan nilainilai sejenis apa yang hendak ditanamkan, dipahatkan kepada lukisan-lukisan anakanak kita di dalam pengetahuannya, sebagai tunas bangsa yang diharapkan memimpin negeri ini dengan basis pendidikan agama islam di sekolah negeri (Nur Khalik, 2017: 7).

Berangkat dari realitas diatas, banyak gagasan untuk menafsirkan agama (Islam) dikaitkan dengan corak kehidupan di Indonesia yang beragam. Beberapa diantaranya menawarkan konsep "Islam Inklusif" yang secara umum dapat diartikan dengan Islam yang terbuka, artinya mengakui adanya nilai-nilai kebenaran pada agama lain demi kerukunan dan kedamaian umat. Namun demikian pengakuan atas agama lain tidak berarti mencampuradukkan pahampaham agama lain bercampur dengan Islam. Islam Inklusif berupaya menawarkan Islam sebagai agama yang Rahmatal lil'alamin yang terimplementasikan dalam kehidupan sehari-hari. Sifat ajarannya yang inklusif diharapkan mampu menjawab isu-isu global seperti humanisme, pluralisme, gender dan lain sebagainya.

Dalam hal ini penulis mencoba menawarkan pilihan pelayanan pendidikan yang inklusif bagi para peserta didik di sekolah dan juga menawarkan metode pembelajaran bagi guru Pendidikan Islam khususnya.

\section{KONSEP PENDIDIKAN INKLUSIF}

Misi utama manusia diciptakan ke dunia adalah humanisasi, suatu proses untuk menjadikan manusia yang lebih manusiawi. Sebagai suatu proses, humanisasi melibatkan kesadaran kritis yang merupakan potensi kodrati manusia. Hal ini untuk membekali manusia dalam upaya memahami realitas dunia dan menciptakan struktur budaya baru. Dengan kesadaran kritis, manusia hadir di dunia tidak hanya berada didalamnya, melainkan ada bersamanya, keberadaannya mengisi ruang kosong dalam realitas kehidupan (Umiarso, 2011: 169). 
Penafsiran tentang pendidikan Inklusif sesungguhnya cukup beragam sesuai dengan sudut pandang pengkaji dalam menguraikan makna substansial dari pendidikan inklusif itu sendiri. Karagaman penafsiaran secara tidak langsung telah menjadi cermin dari keterbukaan pendidikan bagi semua kalangan, baik karena perbedaan latar belakang kehidupan maupun perbedaan fisik yang tidak normal (M. Takdir, 2013: 23). Banyak orang menganggap pendidikan inklusif sebagai versi lain dari pendidikan khusus (special education). Akan tetapi bila dicermati konsep yang mendasari pendidikan inklusif sangat berbeda dengan konsep yang mendasari pendidikan khusus. Konsep pendidikan inklusif mempunyai banyak kesamaan dengan konsep yang mendasari pendidikan untuk semua dan konsep tentang perbaikan sekolah (M Takdir, 2013: 24).

Kata Inklusif mengindentifikasikan sebagai sikap terbuka, toleran dan mau menerima orang lain. Menurut Dr. Alwi Shihab sebagaimana dikutip oleh Wahid Irfan Maghfuri dalam skripsinya menjelaskan bahwa konsep pendidikan Islam inklusif harus dibangun dengan landasan pemahaman mengenai perbedaan yang merupakan sunatullah, memiliki pluralisme agama dan semangat toleransi (Wahid Irfan, 2013: 23). Beliau menambahkan bahwa agama lebih banyak berhubungan dengan hati (iman) ketimbang resiko. Maka agama mengandung dimensi subjektivitas, dalam arti pengalaman keagamaan per-individu yang sulit ditelusuri. Sedangkan pada pendekatan normatif adalah upaya untuk menjelaskan sebuah agama dengan menitikberatkan kebenaran doktrinal dan keunggulan sistem nilai. Pendekatan ini akan menggunakan cara-cara yang bersifat persuasif apologetik dalam mempertahankan keunggulannya. Disinilah terjadi dalam membandingkan suatu agama dengan agama lain, dengan penekanan unsur-unsur "kelemahan dan kekurangan" selalu ditonjolkan (Hujair, 2017: 14).

Senada dengan pendapat Alwi Shihab, penulis juga mendifinisikan Pendidikan inklusif sebagai usaha sadar mendewasakan manusia melalui upaya yang terstruktur dan berkesinambungan dengan sistem pembelajaran yang terbuka, dinamis dan rasional untuk mencapai kedamaian dan kesejahteraan bermasyarakat. Terbuka dengan perbedaan pandangan dalam memahami agama, dinamis dengan tidak stagnan dalam memahami agama dan rasional dengan mengedepankan akal sebagai pondasi dalam mempertahankan keyakinan. Sebagaimana pepetah Jawa mengatakan, "Anglaras ilingin banyu, angeli ananging ora keli" .

Filosofi pendidikan inklusif sebenarnya hampir sama dengan falsafah bangsa Indonesia yaitu Bhineka Tunggal $I k a$, yaitu ketika founding father kita menanamkan falsafah keberagaman dalam kehidupan bernegara tetapi memiliki satu tekat yang sama. Hal ini menunjukkan bahwa bangsa kita telah memahami benar arti perbedaan dan keberagaman yang terdapat di masyarakat (Dadang Garnida, 2015: 41).

Dalam konteks masyarakat saat ini, pluralitas sosial termasuk di dalamnya pluralitas keagamaan, adalah realitas yang tidak mungkin untuk dihindari. Pola hubungan antar komunitas beragama (religious community) semakin meningkat dan menunjukkan kompleksitasnya. Sangat jarang ditemukan adanya komunitas beragama yang terisolasi dari dunia luar. Dinding pemisah yang dahulu menghambat jalur komunikasi antar komunitas, kini seolah telah tertembus oleh kemajuan jaringan komunikasi, sebagai konsekuensi dari majunya ilmu pengetahuan dan teknologi. Jika demikian, maka tidak berlebihan apabila ada yang mengatakan bahwa gejala meningkatnya pluralitas keagamaan sebagaimana 
pluralitas-pluralitas yang lain seperti pluralitas etnik, pluralitas budaya dan pluralitas bahasa telah menjadi semacam hukum alam (sunnatullah). Mengingkari keberadaannya maka sama dengan mengingkari hukum alam.

Menurut Zuly Qodir praktek pelayanan pendidikan agama yang inklusif perlu dilakukan sebagai berikut (Zuly Qodir, 2008: 7):

a. Visi Pendidikan

Visi pendidikan harus dibawa untuk menumbuhkan lingkungan yang kondusif sehingga mampu menghasilkan praktek pendidikan yang menyenangkan pada peserta didik yang nantinya akan mampu membangun masa depan bangsa dengan akal sehat, tidak korup, manipulatif, dsb.

b. Misi Pendidikan

Misi pendidikan harus mampu mendidik peserta didik yang bisa hidup mandiri dan bersama-sama secara sosial, sebab mereka akan hidup ditengah masyarakat yang beragam.

c. Suasana

Pendidikan dilaksanakan dengan penuh perasaan kasih sayang, cinta dan tidak normatif. Pendidikan yang menekannkan dimensi formalitas doktriner sudah seharusnya dikurangi porsinya, karena dikhawatirkan jika doktrin-doktrin agama pada peserta didik tidak disertai dengan penjelasan yang memadai justru akan mengembangkan cara pandang dan sikap sebagaimana tergambar dalam penjabaran doktrin tersebut.

d. Kehadiran Beragam Pendidik

Pelayanan pendidikan agama yang Inklusif dapat dilaksanakan dengan menghadirkan pendidik yang beragam pada sekolah-sekolah yang memiliki ciri khusus keagamaan, seperti sekolah Muhammadiyah, Nahdatul Ulama atau bahkan sekolah non-Islam. tenti ini sulit, akan tetapi jika ada niat baik dari semua pihak untuk menciptakan pemahaman yang setara antar umat beragama, pendidikan agama akan lebih baik kalau disampaikan oleh guru yang beragama sama dengan siswa-siswanya.

e. Kisah-kisah tentang Figur-figur Teladan

Memperbanyak kisah-kisah salafushalih (kisah-kisah lama yang penuh dengan keteladanan) sangat membantu dalam pembentukan akhlak.

f. Melihat Kondidi Riil Kehidupan Masyarakat

Pendidikan agama harus mampu menyapa masyarakat sehingga menumbuhkan sikap dan cara pandang yang manusiawi atas umat manusia, membeda-bedakan agama akibat kuatnya formalisasi agama dalam pendidikan agama selama ini.

g. Kunjungan Persaudaraan

Pendidikan agama Islam dikemas dalam bentuk kunjungan ke tempattempat ibadah agama lain.

h. Menumbuhkan Kecerdasan Emosional

Sikap dan cara yang inklusif dalam pendidikan agama Islam sebagaimana telah disebutkan diatas akan menumbuhkan sikap dan kecerdasan emosional pada peserta didik. Karakteristik kecerdasan emosional menurut Zuly Qodir meliputi, (1) tidak memandang agama yang berbeda secara negatif, (2) Bersedia melalukan perbuatan baik kepada orang lain tanpa melihat agamanya, (3) tidak memandang agamanya sebagai superior dihadapan agama lain. Dan (4) berani mengoreksi dan kritis atas keimanannya setiap saat.

\section{PENDIDIKAN INKLUSIF DALAM QS. AL- HUJURAT AYAT 10-13}

Sikap toleran dalam kehidupan beragama akan terwujud dengan adanya kebebasan dalam masyarakat untuk memeluk agama sesuai dengan keyakinannya masing-masing (Lajnah, 2014 : 17). Inklusifitas dalam beragama juga turut andil dalam persatuan manusia yang majemuk. Menurut Sayyid Quttub bahwa sudah seharusnya Islam memberikan suasana partisipasi sosial, perlakuan yang baik dan pergaulan 
kepada mereka yang berbeda pandangan terhadap kita (Lajnah, 2014: 23). Khususnya di Indonesia, sebagaimana kita ketahui bahwa kebhinekaan dalam memandang agama Islam itu sendiri masih beragam. Terbukti dengan adanya sejumlah organisasi-organisasi masyarakat yang mengatasnamakan Islam. Dari beragam pandangan tersebut terkadang dari sebagian golongan masih ada yang saling menjatuhkan bahkan saling mengkafirkan. Hal tersebut membuktikan adanya krisis toleransi diantara penganut organisasi masyarakat tersebut. Padahal sebagaimana kita ketahui dalam pasal 21 UU RI Tahun 2013 tentang Organisasi Masyarakat menyatakan bahwa setiap organisasi masyarakat mempunyai kewajiban untuk menjaga perdamaian dan menjaga keutuhan NKRI (UU RI, 2013: 2).

Menurut hemat penulis, bahwa adanya krisis toleransi tersebut terjadi karena kurangnya pemahaman masyarakat akan nilai-nilai toleransi dalam beragama. Hal tersebut dikarenakan sejak dibangku sekolah, masyarakat Indonesia telah didoktrin dengan Pendidikan Islam yang normatif. Dimana secara umum, pendidikan Islam di Indonesia dipengaruhi oleh pendidikan di masyarakat yang eksklusif. Eksklusif menurut Hujair adalah sikap tertutup, jumud, dan rigit. Eksklusifisme berusaha untuk menjadikan agama yang banyak sebagai salah satu yang facet (segi) dari agama yang satu (Hujair, 2017: 8).

Dalam Al-Qur'an sebenarnya gagasan tentang pendidikan Inklusif termaktub dalam beberapa ayat. Diantara salah satunya adalah Qs. Al-Hujurat/49 : 10 - 13. Dimana dalam surah tersebut memaparkan tentang etika atau akhlak dalam berhubungan antar sesama manusia. Berikut akan disampaiakan tentang surah al-Hujurat/49 ayat $10-13$ beserta tafsirnya.

Sebagaimana dijelaskan dalam AlQur'an Surah al-Hujurat ayat 10 bahwa setiap mukmin adalah bersaudara. Berikut pemaparannya.

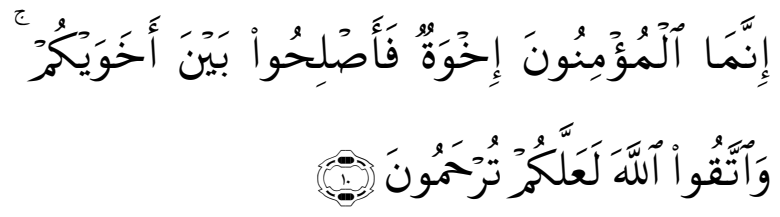

Artinya: Sesungguhnya orang-orang mukmin adalah bersaudara, maka itu damaikanlah kedua saudaramu itu dan bertakwalah kepada Allah supaya kamu mendapat rahmat.

Dalam kitab Tafsir Jalalain, terdapat perbedaan qiraat dalam penggunaan kata ikhwah. Dalam qiraat lain disebutkan dengan menggunakan kata ikhwatikum yang artinya saudara-saudara kalian (Jalaludin Mahali, 2013: 893). Menurut Quraish Shihab dalam kitabnya Tafsir Misbah menambahkan bahwa orangorang mukmin yang mantap imannya serta dihimpun oleh keimanan, kendati tidak seketurunan, adalah bagaikan bersaudara seketurunan, dengan demikian mereka memiliki keterkaitan bersama dalam iman dan juga keterkaitan bagaikan seketurunan (Shihab, 2009: 598). Hal tersebut menunjukkan adanya hubungan kedekatan antara sesama muslim sebagaimana kedekatan dengan saudara kerabat kita. Walaupun orangorang mukmin tersebut berbeda-beda bangsa, etnis, bahasa, warna kulit dan adat kebiasaannya serta stratifikasi soalnya, akan tetapi mereka adalah satu dalam persaudaraan Islam (Amiri, 2015: 151). Sehingga jika terjadi perselisihan (bersengketa) antara segolongan muslim hendaknya diupayakan ishlah antar mereka dalam satu ikatan ukhwah Islamiyah.

Persaudaraan memang kunci sukses dalam dalam menciptakan dan melestarikan tata kehidupan masyarakat yang baik, terhormat dan bermartabat. Sejarah telah mencatat nilai positif dari persaudaraan tersebut, sebagaimana dicontohkan oleh Rasulullah saw yang telah mempersatukan kaum muhajirin 
(dari Mekkah) dengan kaun Ansar (Penduduk asli Madinah). Abu Bakar ashShidiq beliau mempersaudarakan dengan 'Utbah bin Malik, demikian juga dengan sahabat lain (Amiri, 2015: 151). Untuk mendukung persaudaraan yang kukuh diantara kaum muslimin akan dibutuhkan akhlak atau moral yang melandasi sikap dan perilaku yang baik diantara sesama manusia. Dalam hal ini sikap toleransi yang inklusif sangat berperan dalam pemersatuan tersebut.

Setelah ayat yang lalu memerintahkan untuk melakukan ishlah akibat pertikaian yang muncul, dalam ayat selanjutnya akan dipaparkan beberapa hal yang harus dihindari untuk mencegah timbulnya pertikaian yakni surah alHujurat ayat 11 sebagai berikut.

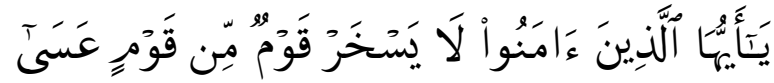

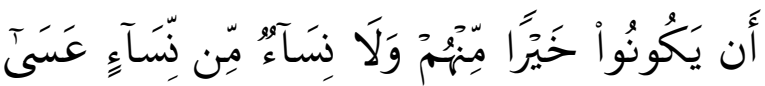

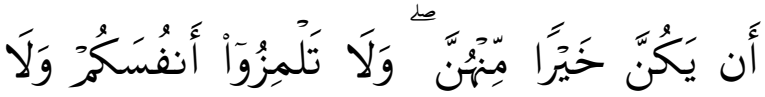

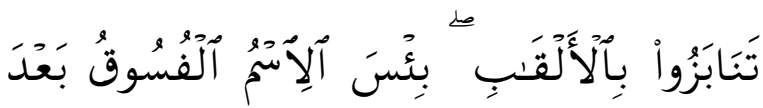

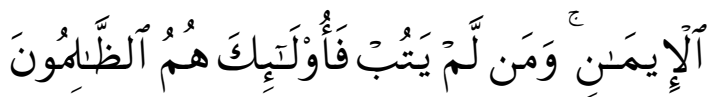

Artinya: Hai orang-orang yang beriman, janganlah suatu kaum mengolok-olokkan kaum yang lain, (karena) mungkin mereka (yang diolok-olok) itu lebih baik daripada yang memperolok-olokkan dan jangan pula wanita-wanita (mengolok-olokkan) wanita-wanita lain, (karena) mungkin wanita-wanita (yang diprolok-olok) itu lebih baik daripada wanita (yang mengolok-olok) dan janganlah kamu mencela dirimu sendiri dan janganlah kamu panggil-memanggil dengan gelargelar yang buruk. Seburuk-buruknya panggilan ialah (panggilan) yang buruk sesudah iman, dan barang siapa yang tidak bertobat, maka mereka itulah orang-orang yang dzalim.

Sikap ekslusif dengan menganggap dirinya paling benar akan memicu suatu perpecahan dalam sebuah komunitas. Hal tersebut juga akan menimbulkan cara berfikir radikal yang nantinya akan berakhir dengan konsep Islam-Kafir. Padahal dalam ayat diatas disebutkan untuk tidak saling mengolok-olok ataupun memanggil dengan gelar-gelar yang buruk karena hal tersebut akan memicu kepada pertikaian. Dalam Tafsir Misbah juga dijelaskan makna kata يسخز (memperolokolok) yaitu menyebut kekurangan pihak lain dengan tujuan menertawakan yang bersangkutan, baik dengan ucapan, perbuatan atau tingkah laku (Quraish Shihab, 2009: 606). Pertikaian dapat dicegah dengan adanya sikap toleransi, menyadari bahwa perbedaan adalah rahmatal lil 'alamin. Memberikan pengakuan dan penghormatan terhadap eksistensi agama lain bukan berarti mengakui kebenaran ajaran tersebut, melainkan lebih kepada menciptakan suasana yang damai dan sejahtera.

Lebih dari itu, Allah swt dalam ayat berikutnya juga menegaskan bahwa manusia dilarang untuk berperasangka buruk terhadap manusia yang tidak memiliki indikator memadai, karena sebagian dari dugaan yang tidak memiliki indikator tersebut adalah dosa. Begitu juga dengan mencari-cari kesalahan orang lain, dan menggunjing. Sebagaimana tertuang dalam ayat 12 .
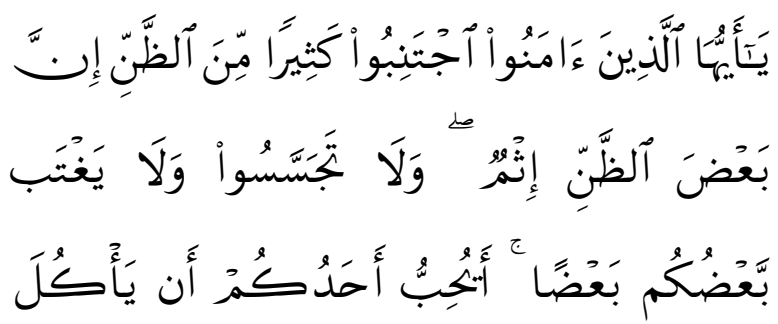

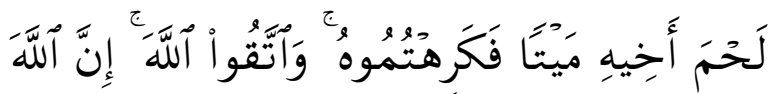

$$
\text { تَوَّابُ رََّحِيمُ }
$$

Artinya: Hai orang-orang yang beriman, jauhilah kebanyakan prasangka, sesungguhnya sebagian prasangka itu adalah dosa dan janganlah kamu mencaricari kesalahan orang lain dan sebagian 
darimu janganlah menggunjing sebagian yang lain. Sukakah salah seorang diantara kamu memakan daging saudaranya yang sudah mati? Tentu kamu merasa jijik kepadanya. Dan bertakwalah kepada Allah. Sesungguhnya Allah Maha Penerima tobat lagi Maha Penyayang.

Pada ayat di atas, kata فكرهتموه (maka kamu telah jijik kepadanya) mengandung sekian banyak penekanan untuk menggambarkan betapa buruknya menggunjing (Quraish Shihab, 2009: 612). Menurut Thabathaba'i ghibah merupakan perusakan bagian dari masyarakat satu demi satu sehingga dampak positif yang diharapkan dari wujudnya satu masyarakat menjadi gagal dan berantakan. Yang diharapkan dari wujudnya satu masyarakat adalah hubungan yang harmonis antar anggotaanggotanya, dimana setiap orang dapat bergaul dengan penuh rasa aman dan damai. Tujuan manusia dalam upayanya membentuk masyarakat adalah agar masing-masing dapat hidup didalamnya dengan satu identitas yang baik sehingga dia dapat (dalam interaksi sosialnya) menarik dan memberi manfaat.

Dari ayat diatas terlihat bahwa alQur'an ketika menguraikan tentang persaudaraan antara manusia sesama muslim, yang ditekankan adalah tentang ishlah, sambil memerintahkan agar menghindari hal-hal yang dapat menimbulkan kesalahpahaman. Rasul saw pun melukiskan petunjuk serupa. Beliau melukiskan dampak persaudaraan dalam bentuk menafikan hal-hal buruk, bukan hanya menetapkan hal-hal baik. Beliau bersabda :"Muslim adalah saudara muslim yang lain. Ia tidak menganiaya, tidak menyerahkan kepada musuhnya, tidak membenci, tidak saling membelakangi, tidak bersaing secara tidak sehat dalam jual-beli, tidak mengkhianatinya, tidak membohonginya, dan tidak meninggalkannya tanpa pertolongan".

Selain itu dalam Al-Qur'an Surah alHujurat ayat 13 juga mengaskan kepada semua manusia bahwa mereka diciptakan Allah swt secara pluralistik, berbangsa, bersuku yang bermacam-macam dengan keberagaman dan kemajemukan bukan untuk saling berpecah belah atau saling merasa benar, melainkan untuk saling mengenal, bersilaturohim, berkomunikasi, serta saling memberi dan menerima.

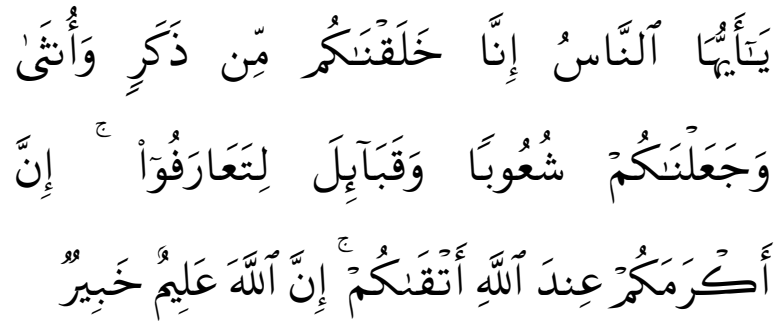

Artinya: Wahai manusia, sesungguhnya Kami menciptakan kamu dari seseorang laki-laki dan seorang perempuan dan menjadikan kamu berbangsa-bangsa dan bersuku-suku supaya kamu saling mengenal. Sesunguuhnya orang yang paling mulia disisi Allah ialah orang yang paling bertakwa diantara kamu. Sesungguhnya Allah Maha Mengetahui lagi Maha Mengenal.

Pada ayat diatas memaparkan bahwa al-Qur'an sangat menghormati prinsip-prinsip kemajemukan yang merupakan realitas yang dikehendaki oleh Allah swt. Perbedaan tersebut tidak harus dipertentangkan sehingga harus ditakuti, melainkan harus menjadi titik tolak untuk berkompetisi dalam kebaikan. Allah swt menciptakan manusia secara pluralistik, berbangsa dan bersuku yang bermacammacam dengan keaneragaman dan kemajemukan manusia bukan untuk berpecah belah atau saling merasa benar, melainkan untuk saling mengenal, bersilaturohim, berkomunikasi, serta saling memberi dan menerima.

Kرف terambil dari kata تعارفوا yang artinya mengenal. Patron kata yang digunakan ayat ini mengandung makna timbal balik, dengan demikian ia berarti saling mengenal. Semakin kuat pengenalan satu pihak kepada selainnya, makan semakin terbuka peluang untuk saling memberi manfaat. Karena itu, ayat 
diatas menekankan perlunya saling mengenal. Perkenalan itu dibutuhkan untuk saling menarik pelajaran dan pengalaman pihak lain guna meningkatkan ketaqwaan kepada Allah swt yang dampaknya tercermin pada kedamaian dan kesejahteraan hidup duniawi dan kebahagiaan ukhrawi.

Berdasarkan tafsir diatas, dapat diambil kesimpulan bahwa untuk mencapai suatu kedamaian dan kesejahteraan dalam bermasyarakat perlu adanya sikap saling terbuka dimulai dengan adanya kesediaan untuk saling menganal antara satu sama lain dan saling menghargai perbedaan dengan tidak melakukan diskriminasi terhadap golongan tertentu. Hal tersebut akan terlaksana dengan mengenalkan pendidikan Inklusif yang terbuka di mulai dari bangku sekolah.

Dalam konteks ini, pembelajaran Pendidikan Agama Islam adalah suatu upaya untuk membuat peserta didik dapat belajar, butuh belajar, terdorong belajar, mau belajar dan tertarik untuk terus menerus mempelajari agama Islam, baik untuk mengetahui bagaimana cara beragama yang benar maupun mempelajari Islam sebagai pengetahuan. Akan tetapi persoalan yang terjadi adalah jika proses pembelajaran pendidikan agama Islam tersebut yang 'salah', bahkan dapat menjadikan seseorang 'menjadi radikal'. Ada dibeberapa sekolah, siswa bukan diperkenalkan dengan ajaran agama yang penuh cinta damai, namun justru dikenalkan dengan ajaran doktrin yang keras, agresor, dan pembalas dendam. Selain itu juga didukung dengan kurikulum pendidikan agama yang berorinentasi pada hukum/fikih yang kaku dan eksklusif. Padahal Islam adalah ajaran yang sangat berorientasi pada ajaran cinta yang rahmatal lil 'alamin.

Untuk mencegah lahirnya paham radikalisme di sekolah, perlu adanya rombakan mindset terhadap agama Islam itu sendiri. Cara mengajarkan pelajaran agama kepada para peserta didik. Peran guru sebagai pendidik menduduki posisi sentral. Sebab ditangan merekalah, peserta didik dapat dibentuk cara pandangnya terhadap agama dengan kacamata rahmatal lil alamin. Maka pendidik seperti disebut oleh Musaddad (2016: 102) hendaklah menempatkan diri sebagai guru semata tanpa menampilkan dirinya sebagai pendidik berkedok penguasa. Oleh karena itu, dengan berdasarkan QS. al-Hujurat ayat 10 - 13 tersebut, penulis mengajak kepada para guru dan atau calon pendidik muda untuk melakukan redisgn kurikulum dan metodologi pembelajaran dari ajaran berbasis ekslusif kepada pembelajan inklusif sebagaimana penulis tawarkan sebelumnya. Pembelajaran dengan nilainilai agama yang Inklusif di kelas, proses pendidikan agama yang moderat, serta agama yang cinta kasih.

\section{PENDIDIKAN INKLUSIF SEBAGAI SOLUSI EKSKLUSIFISME PENDIDIKAN ISLAM DI SEKOLAH}

Secara umum, pendidikan agama di Indonesia dipengaruhi oleh pendidikan di masyarakat, khususnya pendidikan yang diajarkan di sekolah atau perguruan tinggi yang cenderung eksklusif yaitu pendidikan yang intoleran, bervisi eksklusif, menafikan realitas kebangsaan Pancasila yang akan menjadi pemanik bagi kecenderungan kekerasan yang berbasiskan keyakinan yang eksklusif. Dengan demikian, akan muncul suatu pembelajaran yang mengutamakan kebenaran bersama dan tidak menggunggulkan satu golongan tertentu.

Berangkat dari epistemologi Paulo Freiere tentang kaum tertindas (oppressed) dalam pendidikan pembebasan bahwa pendidikan harus mampu memberikan ruang kosong bagi peserta didik untuk melakukan improvisasi diri dalam menemukan eksistensi dirinya. Peserta didik yang menginternalisasi citra diri kaum penindas dan menyesuaikan diri dengan 
jalan pikiran mereka akan membawa keterbelengguan diri dan rasa takut yang berat pada diri peserta didik.

Ketika membahas tentang pendidikan Inklusif ditingkat sekolah atau madrasah ada sesuatu yang sangat mengerikan. Sejauh yang kita ketahui bahwa pendidikan agama di tingkat sekolah atau madrasah cenderung mengarah pada adanya penguatanpenguatan ideologis dan keagamaan yang hanya mau menerima kebenaran moral dari agamanya saja sehingga tidak jarang menghasilkan lulusan-lulusan yang sektarian. Dalam pandangan penulis, hal tersebut disebabbkanan oleh materi pembelajaran yang truth of claim imankafir, ajaran normatif, dan doktrin nilainilai agama.

Solusi yang kerap ditawarkan sering dimulai dari aspek kurikulum, yaitu dengan redesign kurikulum pendidikan Islam yang berspektif inklusif. Menitikberatkan lewat pemahaman kurukulum memang tidak tidak salah karena kurikulum merupakan aspek sentral dalam seluruh proses pendidikan di sekolah. Akan tetapi, bagaimana mungkin konsep kurikulum yang inklusif akan dapat terealisasi dengan sempurna jika guru dalam sekolah tersebut cenderung memiliki perspektif konservatif-eklsklusif.

Pemilihan paradigma ideologi penting supaya tujuan dan misi pendidikan dapat terlaksana dengan mendekati sempurna atau sekurangkurangnya sesuai dengan kehendak para penyelanggara pendidikan berbasis inklusif. Berkaitan dengan Pendidikan Islam, menentukan paradigma ideologi harus diimbangi dengan pendampingan yang serius. Karena kesalahan dalam menentukan paradigma ideologi dikhawatirkan akan menghasilkan peserta didik atau siswa yang justru tidak bersikap inklusif melainkan berada pada ujung ekstrem lainnya, entah ekstrem kanan (kaum fundamentalis-radikal) atau ekstrem kiri sebagai kaum liberalmarxian.

Menurut Sapon-Selvin sebagaimana dikutip oleh Hujair dalam makalahnya menyatakan bahwa ada lima profil pembelajan inklusif, meliputi (1) Pembelajaran Inklusif berarti menciptakan dan menjaga komunitas kelas yang hangat, menerima keaneragaman, dan menghargai perbedaan; (2) Pembelajaran Inklusif berarti penerapan kurikulum yang multilevel dan multi modalitas; (3) Pembelajaran Inklusif berarti menyiapkan dan mendorong guru untuk mengajar interaktif; (4) Pembelajaran Inklusif berarti penyediaan dorongan bagi guru dan kelasnya secara terus-menerus dan penghapusan hambatan yang berkaitan dengan isolasi profesi, dan (5) Pembelajaran Inklusi berarti melibatkan orang tua secara bermakna dalam proses percakapan.

Ada beberapa metode pembelajaran yang penulis tawarkan dalam menyikapi pendidikan indoktrinitas di sekolah khususnya di sekolah tingkat Menengah. Sebagai berikut.

\section{a. Metode Pembelajaran CTL (Contextual Teaching and Learning)}

Berdasarkan pendapat para ahli, CTL adalah konsep belajar yang membantu guru mengkaitkan antara materi yang diajarkanya dengan situasi dunia nyata siswa dan mendorong siswa membuat hubungan antara pengetahuan yang dimilikinya dengan penerapan dalam kehidupan sehari-hari.

Sistem pembelajaran CTL ini bertujuan untuk memotivasi siswa untuk memahami makna materi akademik yang dipelajarinya dengan mengkaitkan materi tersebut dengan konteks kehidupan mereka sehari-hari sehingga siswa memiliki pengetahuan atu ketrampilan yang secara refleksi dapat diterapkan dari permasalahan

kepermasalahan lainya. Selain itu, pembembelajaran ini juga diharapkan dapat memberikan 
paradigma baru untuk belajar siswa agar tidak hanya sekedar menghafal tetapi perlu dengan adanya pemahaman materi.

Sistem CTL mencakup delapan komponen berikut: (1) Membuat keterkaitan-keterkaitan yang bermakna, (2) melakukan pekerjaan yang berarti, (3) melakukan pembelajaran yang diatur sendiri, (4) Bekerja sama, (5) Berfikir kritis dan kreatif, (6) membantu individu untuk tumbuh dan berkembang, (7) mencapai standar yang tinggi, dan (8) menggunakan penilaian autentik.

\section{b. Metode Pembelajaran Kritis}

Desain pembelajaran salah satunya yaitu ketrampilan berpikir kritis dan ketrampilan berpikir kreatif. Desain ini sebenarnya sama dengan desain pembelajaran inkuiri yaitu membantu anak berlatih dan memecahkan berbagai masalah kehidupan pribadi maupun kemasyarakatan oleh karena itu desain pembelajaran inkuiri akan sangat membantu proses pembelajaran berpikir kritis.

Ketrampilan berpikir kritis adalah kemampuan untuk mengatakan sesuatu dengan penuh percaya diri. Berfikir kritis merupakan perbuatan seorang yang mempertimbangkan , menghargai , menaksir nilai suatu hal. Tugas orang yang berfikir kritis adalah menerapkan norma dan standar yang tepat terhadap suatu hasil dan mempertimbangkan nilanya dan mengartikulasikan pertimbangan tersebut. Jadi menurut Johnson berpikir kritis adalah ketika orang bertemu dengan sesuatu hal, lalu orang tersebut tidak langsung menerima secara mentah-mentah melainkan menelaah lebih dalam hal yang datang tersebut sehingga orang tersebut bisa memahami dan menyaring hal yang datang tersebut. Kemudian jika lebih lanjut hal tersebut bisa dimaknai oleh penilaian atau pertimbangan orang tersebut.

Tujuan berpikir kritis adalah untuk mencapai pemahaman yang mendalam.
Pemahaman membuat kita mengerti maksud dibalik ide yang mengarahkan hidup setiap hari. Pemahaman mengungkapkan makna dibalik suatu kejadian. Berfikir kritis memungkinkan peserta didik untuk menemukan kebenaran ditengah banjur kejadian dan informasi yang mengelilingi mereka setiap hari.

Dalam ranah pendidikan media kritis, Ellsworth dan Whatley sebagaimana dikutip oleh Prof H.A.R Tilaar menerangkan bahwa ia mencoba membuat analisis ideologis mengenai media-media yang digunakan dalam pendidikan termasuk diantaranya film dan televisi. Ranah lain yang lebih abstrak dari teknologi pendidikan yang mendapatkan perhatian dari pendekatan kritis adalah etika, bahwa teknologi pendidikan tidak dapat dilepaskan dari tanggung jawab etisnya

Model analisi teknik "brainstorming", salah satu teknik / ketrampilan berpikir kreatif sebagai model ketrampilan berpikir kritis yang dikembangkan oleh Dunn and Dunn (1972), langkahlangkahnya adalah guru mendorong siswa untuk memikirkan cara terbaik untuk memecahkan masalah, ketika guru sudah mendorong siswa untuk memecahkan kemudian guru memberi pertanyaan kenapa pemikiran tersebut belum terlaksana juga misalnya apakah pemikiran pemecahan tersebut terdapat kendala? Dan sebagainya. Dan pada saat siswa menjawab pertanyaan ini, guru membantu siswa lainnya yang sedang berpikir, kemudian guru meminta siswa memikirkan masalah yang mungkin dihadapi dalam menjawab pertanyaan terdahulu, dan tahap yang terakhir siswa diminta untuk menentukan langkah pertama untuk memecahkan masalah.

\section{c. Pembelajaran Inkuiri}

Inquiry berasal dari kata to inquire yang berati ikut serta atau terlibat dalam mengajukan pertanyaan, mencari informasi, dan melakukan penyelidikan. 
Adapun tujuan dalam model pembelajar inkuiri menurut Bruner adalah bahwa guru memberikan kesempatan kepada muridnya untuk menjadi seorang problem solver, seorang saintis, ahli sejarah, penemu atau ahli matematika.

Inkuiri melibatkan komunikasi yang berarti tersedia suatu ruang, pandang, dan tenaga bagi siswa untuk mengajukan pertanyaan dan pandangan yang logis, objektif, dan bermakna. Inquiri memungkinkan guru belajar tentang siapakah siswa mereka, apa yang siswa ketahui, dan bagaimana pikiran siswa mereka bekerja sehingga guru dapat menjadi fasilisator yang lebih efektif berkat adanya pemahaman guru terhadap peserta didiknya. Inkuiri menghendaki peserta didik untuk mengambil tanggung jawab atas pendidikan mereka sendiri.

\section{PENUTUP}

Dari kajian yang telah dilakukan dapat disimpulkan, pendidikan inklusif adalah suatu keharusan. Tawaran pelayanan pendidikan inklusif ini idealnya menjadi pertimbangan bagi para penyelenggara pendidikan, sebab dengan layanan pendidikan yang inklusif ini para peserta didik dapat ditumbuhkembangkan kearah yang lebih baik, sehingga peserta didik memiliki sikap toleran dalam kehidupan, terutama dalam kehidupan beragama.

Ketidak pedulian terhadap model pendidikan inklusif akan membawa dampak negative yaitu terbentuknya peserta didik yang eksklusif, yaitu susah menerima sesuatu yang datang dari luar dirinya. Padahal eksistensi manusia tidaklah dapat dilepas dari kehidupan social.

Untuk menopang efektivitas dan efesiensi pendidikan inklusif ini ada beberapa metode yang dapat dipergunakan, seperti metode pembelajaran CTL, Inkuiri, dan Metode Pembelajaran Kritis.[] 


\section{DAFTAR RUJUKAN}

AH, Hujair. Menyemai Nilai-nilai InklusifToleran dalam Pendidikan Agama. Disampaikan pada Seminar Nasional "Pendidikan agama yang Inklusif dalam Menangkal Radikalisme Agama di Perguruan Tinggi". Diselenggarakan oleh Prodi PAI FIAI UII bekerjasama dengan HMJ PAI UII, bertempat diruang Auditorium gedung Perpustakaan Pusat UII tanggal 9 Oktober 2017.

Faturrohman, Muhammad. Model-model Pembelajaran Inovatif, Yogyakarta: Ar-Ruzz Media, 2015.

Garnida, Dadang. Pengantar Pendidikan Inklusif, Bandung: Refika Aditama, 2015.

Harahap, Musaddad. Refleksi Dinamika Kebebasan Akademis dalam Pendidikan Islam. Jurnal Pendidikan Agama Islam Al-Thariqah 1.1 (2017): 87-103.

Hitami, Munzir. Pengantar Studi Al-Qur'an: Teori dan Pendekatan, Yogyakarta:

Ilahi, Mohammad Takdir. Pendidikan Inklusif: Konsep dan Aplikasi, Jogjakarta: Ar-Ruzz Media, 2013.

Johnson, Elaine B, Contextual Teaching \& Learning: Menjadikan Kegiatan Belajar Mengajar Mengasyikan dan Bermakna, Bandung: Mizan Media Utama, 2007.

Lajnah Pentashihan Mushaf Al-Qur'an. Tafsir Al-Qur'an Tematik, Jakarta: Kamil Pustaka, 2014.

Qadir, Zuly. Membangun Pendidikan Inklusif-Pluralis: Pengalaman Islam. (Online). Vol. 17, 2008.

Ridwan, Nur Khalik, Makalah: Gerakan Islamis di Sekolah-sekolah Negeri, Kritik Tentang Pendidikan Karakter Berbasis PAI. Disampaikan pada Seminar Nasional "Pendidikan agama yang Inklusif dalam Menangkal Radikalisme Agama di Perguruan Tinggi". Diselenggarakan oleh Prodi PAI FIAI UII bekerjasama dengan HMJ
PAI UII, bertempat diruang Auditorium gedung Perpustakaan Pusat UII tanggal 9 Oktober 2017.

Shihab, Alwi, Islam Inklusif : Menuju Sikap Terbuka dalam Beragama. Bandung: Al-Mizan, 1999.

Shihab, M. Quraish. Tafsir Al-Misbah: Pesan, Kesan dan Keserasian Al-Qur'an, Jakarta: Lentera Hati, 2002.

Umiarso, dkk. Pendidikan Pembebasan Dalam Perspektif Barat dan Timur. Jogjakarta: Ar-Ruzz Media, 2011. 